\title{
EXPLORING STUDENTS INTERESTS IN LEARNING ENGLISH (A Descriptive Study in Elementary Schools in Kudus)
}

\author{
Sri Endang Kusmaryati \\ sriendangkusmaryati@yahoo.com \\ Universitas Muria Kudus \\ Indiyah Prana Amertaningrum \\ indiyahprana@gmail.com
}

UNWIDA

\begin{abstract}
Teaching English as a foreign language in Indonesia is a complex task for a teacher. Language learning should be more fun and enjoyable for students to learn. Teachers need to have effective teaching strategies to make students understand English materials better in learning process. A teacher needs to facilitate students' interest towards learning English. For some students, learning English is one of the most difficult subjects they have to learn. Due to the difficulties in learning English, it can make students lose their interest easily. This paper is a descriptive study in some elementary schools in Kudus. The result shows that most of the students in elementary schools in Kudus tend to have high interest in learning English. Knowing this fact, hopefully, teachers will be able to stimulate students' interest more and improve their achievements in learning English.

Key words: Students' Interest, Learning English, Elementary School.
\end{abstract}

\section{INTRODUCTION}

The competence of elementary schools graduates should be appropriate in order to prepare them to learn English at the higher level. Teaching English at elementary schools is intended to develop language skills used to accompany the activities in their life. The policy of Departemen Pendidikan Nasional, No.0487/14/1992, Chapter VIII and Undang-undang Sistem Pendidikan Nasional, No.060/U/1993 states that learning English can be incorporated into the curriculum of local content at elementary schools.

Students of elementary schools are young learners who have their own characteristics. Young learners take great pleasure in having fun in what they do. The elementary school teachers should understand their world. Besides, they also should have the ability to teach them communicatively and they also need skills to teach English effectively based on appropriate teaching model. Therefore, teaching English to elementary schools students must be well designed in accordance with the characteristics of the students. Elementary school students are still in the early age about 6 to 12 years. It implies that teaching English such age should be well managed.

Some elementary schools in Kudus determine English as a local content subject or extra curricular. Even in some elementary schools, moreover English has been taught in the first grade at the first semester. In reference to some personal conversations conducted by the writer with 
some English teachers in Kudus, in the process of teaching and learning in the classroom the students tend be very active playing with their friends and it is hard for them to ask the students to be serious joining the English class..

Interest is one of the strongest motivations for learning English, and motivation has been identified as one of the main factors affecting English language learning (Gardner, 1985). Learning and motivation have the same importance in order to achieve something. While learning makes us gain new knowledge and skills and motivation pushes us to go through the learning process (Wimolmas, 2013).

This paper is aimed at exploring the students' interest in learning English in elementary schools. It describes about the students' interest in learning English, their perceptions in learning English, and their activities in improving English achievements.

\section{LITERATURE REVIEW}

\section{Teaching English to Young Learners}

Teaching English to young learners in Indonesia is issued on the policy of Departemen Pendidikan Nasional, No.0487/14/1992, chapter VIII and Undang-undang Sistem Pendidikan Nasional, No.060/U/1993.It states that learning English can be incorporated into the curriculum of local content at elementary schools. While teachers hopefully consider the appropriate English learning that is the learning that takes into account the child's developmental level both for kindergartens and elementary school students.

As the policy issued, Margana (2015:371) also describes more that in the elementary school level, English is one of the local contents taught optionally. And a great number of elementary schools in Indonesia include English as one of the subjects taught from fourth grade. Even some elementary schools offer English as a local content subject starting from first grade. While in the level of pre-school, English is also taught optionaly. The English in pre-schools aim to motivate students to learn English early. It is also intended to introduce some English vocabulary items, hopefully they will be familiar with the sounds of English and vocabulary items as presented in songs, games, charts, stories, and the rest.

Theories explained by Piaget, Vygoscky, and Bruner should be considered in teaching English to young learners. According to Piaget (Cameron, 2001: 2-4), childrenare active learners and thinkers, constructing their own knowledge from working with objects or ideas. They interact with the world around them, and solve problems presented by the environment. The childrenare also sense makers. Children seek out intentions and purposes how they see other people doing, bringing their knowledge and experience to their attempts to make sense of other people's activity and language.

Vygotsky (Cameron, 2001:5) tells that development and learning take place in a social context. World is full of other people who play important role in helping children to learn, bringing objects and ideas to their attention. And children learn to do things and learn to think through interaction with adults in their social context. While Bruner (Cameron, 2001:8-10) adds that language is the most important tool for cognitive growth, and he has investigated how adults use language to mediate the world for children and help them to solve problems. Talks support children in carrying out an activity, and the talksare called as scaffolding talks. The scaffolding 
talks can be applied in language classroom as routines that happen every day. It will provide chances for meaningful language development. They allow the child to actively make sense of new language from familiar experience and provide a space for language growth, and also open up many possibilities to develop language skills.

Moreover, Clark and Clark (1977) explain that young learners are still in the process of developing their concepts. Young learners do not have real linguistic need. Children rarely have such needs in learning a foreign language. They are still in the process of learning many things at the same time. And Haliwell (1992) confirms the issue of learning English that young learners already have great skills in using limited language creatively. In the early stages of their mother tongue development, children are excellent at making a little language go along away. They learn language through the subconscious or acquisition process more than the direct learning. If their surrounding provides more encouragement, it will help them to learn much.

Based on the description of the children's characteristic, it can be concluded that learning English for students in early age needs a fun and enjoyable learning techniques in order to make them more interested in learningEnglish.

\section{Interest in Learning English}

Learning can be considered as a process of getting knowledge. Student's interest is important in learning and interests also play a important role in developing student's thinking ability. Interestspowerfully influence student's academic and professional choices. That is of course the teacher 's responsibility to establish the relations between student's interest and new knowledge. Whenstudents are interested in what they are learning, hopefully they will pay closer attention, they will also process the information more efficiently, and employ more effective learning strategies, such as engaging in critical thinking, making connections between old and new knowledge, and attending to deep structure instead of surface features. Further, when the students are interested in a task, they will work harder and persist longer, bringing more of their self-regulatory skills into play.

Idit Katz et.all. (2006) call Interest as intrinsic interest or intrinsic value defined as "the enjoyment peopleexperience when doing a task, or their subjective interest in the contentof the task" (Wigfield \& Eccles, 1992, pp. 280).Intrinsic interest may enable children to remain occupied in a task withoutreceiving immediate feedback because it can allow them to perceivethe task as enjoyable and as containing personally meaningful information,which they can connect with various issues that interest them. In addition,children who have an interest in a certain topic, might be able to rely oninternal cues as to how well they are doing due to their experience withsimilar tasks

\section{METHOD}

This paper is the result of the research conducted through an exploratory research. The research focuses on finding out the students' interest in learning English. There are three data collected in this research, namely: 1) the students's interest in learning English, the students's perception in learning English and the students' activities in improving their English skills. The data were collected by using questionaire in 28 elementary schools. Five students were chosen to fill the questionaires purposefully. And the data were analyzed and described in forms of tables. 


\section{FINDINGS AND DISCUSSION}

As mentioned previously, there are three kinds of data collected in the research, namely: the students' interest in learning English, their perceptions of leaning English and also their activities to improve their English skills, and they are presented in the following descriptions.

The Students' Interests in Learning English

The data of the students' interests in learning English were collected through the questionnaire. The students need to answer the questions if they are interested in learning English or not. And the students need to choose the appropriate answer by crossing the option, namely: 1) very interested,2) interested, or 3) uninterested. The result can be presented in Table 1.

Table 1. The Students' Interests in Learning English

\begin{tabular}{|c|c|c|c|c|}
\hline \multirow[b]{2}{*}{ NO. } & \multirow[b]{2}{*}{ Name of Schools } & \multicolumn{3}{|c|}{ Students' Interests } \\
\hline & & $\begin{array}{c}\text { Very } \\
\text { Interested }\end{array}$ & Interested & Uninterested \\
\hline & SD 5 Jekulo & 3 & 2 & - \\
\hline & SD 1 Bulungcangkring & 1 & 3 & 1 \\
\hline & SD 3 Bulungcangkring & 3 & 2 & - \\
\hline & SD 4 Bulungcangkring & 4 & 1 & - \\
\hline & SD 7 Bulungcangkring & 4 & 1 & - \\
\hline & SD $1 \mathrm{Bae}$ & 1 & 4 & - \\
\hline & SD 6 Cendono & 2 & 3 & - \\
\hline & SD 3 Kajar & 2 & 3 & - \\
\hline & SD 1 Colo & 1 & 4 & - \\
\hline & SD 01 Purwosari Kudus & - & 5 & - \\
\hline & SD 02 Purwosari Kudus & 4 & 1 & - \\
\hline & SD N Demangan & 2 & 3 & - \\
\hline & SD 1 Loram Wetan & - & 5 & - \\
\hline & SD 2 Loram Wetan & - & 5 & - \\
\hline & SD 3 Loram & 1 & 4 & - \\
\hline & SD 4 Getas Pejaten & 2 & 3 & - \\
\hline & SD 4 Mejobo & 2 & 3 & - \\
\hline & SD 2 Getassrabi & 3 & 2 & - \\
\hline & SD 1 Padurenan & 2 & 3 & - \\
\hline & SD 1 Karangmalang & 2 & 2 & 1 \\
\hline & SD 4 Kalirejo & 3 & 1 & 1 \\
\hline & SD 2 Medini & 2 & 3 & - \\
\hline & SD 3 Sambung & 3 & 2 & - \\
\hline & SD 3 Undaan Tengah & 3 & 2 & - \\
\hline & SD 2 Kaliwungu & 1 & 4 & - \\
\hline & SD 2 Kedungdowo & - & 4 & 1 \\
\hline & SD 1 Garung Lor & 2 & 3 & - \\
\hline & SD 1 Prambatan Kidul & 2 & 3 & - \\
\hline & TOTAL & 55 & 83 & 4 \\
\hline
\end{tabular}


The $2^{\text {nd }}$ TEYLIN International Conference Proceedings

April 2017

From Table 1, it can be seen that the students' interest in learning English is very high. There are 83 students who are interested in learning English, and 55 students are very interested, while only 4 students are not interested in learning English.

\section{The Students' Perceptions in Learning English}

Beside the students' interest in learning English, the writer also collected the data about the students' perceptions in learning English. In this case the students need to answer the question if learning English is easy or difficult. And the students need to choose the appropriate answer by crossing the option of 1) very easy, 2) easy, 3) difficult, or 4) very difficult. The data is presented in Table 2.

Table 2. The Students' Perceptions in Learning English

\begin{tabular}{|c|c|c|c|c|c|}
\hline \multirow[b]{2}{*}{ NO. } & \multirow[b]{2}{*}{ Name of Schools } & \multicolumn{4}{|c|}{ Students' Perceptions } \\
\hline & & $\begin{array}{l}\text { Very } \\
\text { Easy }\end{array}$ & Easy & Difficult & $\begin{array}{c}\text { Very } \\
\text { Difficult }\end{array}$ \\
\hline & SD 5 Jekulo & - & - & 2 & 3 \\
\hline & SD 1 Bulungcangkring & - & 1 & - & 4 \\
\hline & SD 3 Bulungcangkring & - & 2 & 2 & 1 \\
\hline & SD 4 Bulungcangkring & - & - & 5 & \\
\hline & SD 7 Bulungcangkring & - & - & - & 5 \\
\hline & SD 1 Bae & - & 2 & 1 & 2 \\
\hline & SD 6 Cendono & - & 4 & - & 1 \\
\hline & SD 3 Kajar & - & 2 & 2 & 1 \\
\hline & SD 1 Colo & - & 2 & 3 & - \\
\hline & SD 01 Purwosari & - & 5 & - & - \\
\hline & SD 02 Purwosari & - & 5 & - & - \\
\hline & SD N Demangan & - & 3 & 2 & \\
\hline & SD 1 Loram Wetan & - & 2 & - & 3 \\
\hline & SD 2 Loram Wetan & - & 1 & 3 & 1 \\
\hline & SD 3 Loram & - & 2 & 1 & 2 \\
\hline & SD 4 Getas Pejaten & - & 1 & 3 & 1 \\
\hline & SD 4 Mejobo & - & 1 & 4 & - \\
\hline & SD 2 Getassrabi & - & 3 & 1 & 1 \\
\hline & SD 1 Padurenan & - & 2 & 3 & - \\
\hline & SD 1 Karangmalang & - & 5 & - & - \\
\hline & SD 4 Kalirejo & - & 3 & 2 & - \\
\hline & SD 2 Medini & - & 4 & 1 & - \\
\hline & SD 3 Sambung & - & 5 & - & - \\
\hline & SD 3 Undaan Tengah & - & 4 & 1 & - \\
\hline & SD 2 Kaliwungu & - & 4 & 1 & - \\
\hline & SD 2 Kedungdowo & - & 2 & 1 & 2 \\
\hline & SD 1 Garung Lor & - & 5 & - & - \\
\hline & SD 1 Prambatan Kidul & - & - & 3 & 2 \\
\hline & TOTAL & 0 & 70 & 41 & 29 \\
\hline
\end{tabular}


Table 2 describes that the students (70 students) tend to think that learning English is easy. There are 41 students who have perceptions that learning English is difficult, and 29 students think that it is difficult, while no student thinks that it is very easy.

\section{The Students' Activities in Improving Their English Skills}

The other data is the students' activities in improving their English Skills and the students need to choose the answer by crossing the option, namely: 1) singing English songs, 2) watching English movies, 3) reading English books, or 4) joining English course, but they also can add some other activities they do to improve their English skills, just like playing games through mobile phone, learning through dictionary, or others. The data is described in table 3 .

Table 3. The Students' Activities in Improving Their Skills

\begin{tabular}{|c|c|c|c|c|c|c|}
\hline \multirow[b]{2}{*}{ NO. } & \multirow[b]{2}{*}{ Name of Schools } & \multicolumn{5}{|c|}{ Students' Activities } \\
\hline & & $\begin{array}{c}\text { Singing } \\
\text { English } \\
\text { Songs }\end{array}$ & $\begin{array}{c}\text { Watching } \\
\text { English } \\
\text { Movies }\end{array}$ & $\begin{array}{c}\text { Reading } \\
\text { English } \\
\text { Books }\end{array}$ & $\begin{array}{l}\text { Joining } \\
\text { English } \\
\text { Course }\end{array}$ & Others \\
\hline & SD 5 Jekulo & 3 & - & - & 1 & $\begin{array}{c}\text { Playing } \\
\text { Games } \\
\text { through } \\
\text { HP }\end{array}$ \\
\hline & SD 1 Bulungcangkring & - & - & - & 4 & $\begin{array}{c}\text { Playing } \\
\text { Games } \\
\text { through } \\
\text { HP }\end{array}$ \\
\hline & SD 3 Bulungcangkring & 3 & - & - & 2 & - \\
\hline & SD 4 Bulungcangkring & - & - & - & 5 & - \\
\hline & SD 7 Bulungcangkring & 4 & - & - & 5 & - \\
\hline & SD $1 \mathrm{Bae}$ & 5 & - & 2 & 5 & Games \\
\hline & SD 6 Cendono & 3 & 2 & - & 3 & Games \\
\hline & SD 3 Kajar & 2 & & & 3 & \\
\hline & SD 1 Colo & 2 & & 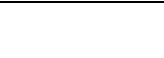 & 3 & \\
\hline & SD 01 Purwosari & - & - & - & 5 & - \\
\hline & SD 02 Purwosari & 3 & 2 & - & - & - \\
\hline & SD N Demangan & - & - & - & 5 & - \\
\hline & SD 1 Loram Wetan & - & - & 1 & 3 & $\begin{array}{c}\text { Grroup } \\
\text { work }\end{array}$ \\
\hline & SD 2 Loram Wetan & - & - & - & 5 & - \\
\hline & SD 3 Loram & - & - & 1 & 3 & $\begin{array}{l}\text { Group } \\
\text { work }\end{array}$ \\
\hline & SD 4 Getas Pejaten & 1 & - & - & 4 & - \\
\hline & SD 4 Mejobo & 1 & - & - & 3 & - \\
\hline & SD 2 Getassrabi & - & - & - & 4 & Learning \\
\hline & SD 1 Padurenan & 1 & - & 1 & 3 & - \\
\hline & SD 1 Karangmalang & 2 & - & - & 3 & - \\
\hline & SD 4 Kalirejo & 2 & - & - & 3 & - \\
\hline & SD 2 Medini & 2 & - & - & 3 & - \\
\hline
\end{tabular}




\begin{tabular}{|l|l|c|c|c|c|c|}
\hline & SD 3 Sambung & 2 & - & - & 3 & - \\
\hline & SD 3 Undaan Tengah & 3 & - & - & 2 & - \\
\hline & SD 2 Kaliwungu & 3 & - & - & 2 & - \\
\hline & SD 2 Kedungdowo & 2 & 1 & - & - & Learning \\
& & & & & & $\begin{array}{c}\text { dictionar } \\
\text { y } \\
\end{array}$ \\
& & & & & $\begin{array}{c}\text { G } \\
\text { Games }\end{array}$ \\
& & & & & & - \\
\hline & SD 1 Garung Lor & - & - & 1 & 4 & - \\
\hline & SD 1 Prambatan Kidul & 5 & - & - & - & \\
\hline & TOTAL & 49 & 5 & 6 & 81 & \\
\hline
\end{tabular}

Table 3 presents that there are 81 students who join English course to improve their English skills, 49 students sing English songs, 6 students read English books, and 5 students watch English movies. Besides, some students also play games through mobile phones, learning dictionary, and group work to improve their English skills.

As mentioned previously students of elementary schools are young learners who have their own characteristics. Young learners take great pleasure in having fun in what they do and they really like to play games. All the data presented above show that most of the students are interested in learning English, and they also have good perceptions about learning English. Besides, they also have good activities in improving their English skills. This condition can support the students to learn English in the process of teaching and learning in the classroom as explained by Gardner (1985) that Interest is one of the strongest motivations for learning English, and motivation is one of the main factors affecting learning English. When students have high interests in learning English, hopefully they will enjoy joining English class and they will pay closer attention to the teacher's explaination, so they will process the information more efficiently. And it is teacher's responsibility to faclitate them to learn English with fun.

\section{CONCLUSION}

\section{Finally, the conclusions of the research are as follow.}

The students of elementary schools in Kudus tend to have high interests in learning English. There are 83 students who are interested in learning English, and 55 students are very interested, while only 4 students are not interested in learning English.

They have good perception in learning English. The students (70 students) tend to think that learning English is easy. There are 41 students who have perceptions that learning English is difficult, and 29 students think that it is difficult, while no student thinks that it is very easy.

Most students of elementary schools (81 students) join English course in improving their English skills. There are 49 students who improve their skill through singing English songs, 6 students through reading English books, and 5 students through watching English movies. While some students also play games through hand phone, learning dictionary, and group work to improve their English skills. 


\section{REFERENCES}

Cameron, L. (2001). Teaching Language to Young Learners. Cambridge: Cambridge University Press.

Cameron, L. and Penny Mckay. (2010). Bridging Creative Teaching into the Young Learner Classroom. New York: Oxford University Press.

Clark, H.M., and E.V. Clark . (1977). Psychology and Language: An introduction to psycholinguistics. New York: Harcount Brace Jovanovich.

Idit Katz, Avi Assor, Yaniv Kanat-Maymon and Yoella Bereby-Meyer. (2006). Interest as a Motivational Resource: Feedback and Gender Mater, but Interest Makes the Difference. Social Psychology of Education (2006) 9:27-42 @ Springer. DOI: 10.1007/s11218-0052863-7

Margana. (2015). Establishing English-Indonesian Bilinguals in Indonesia: From theory to practice. (Electronic Version). Research \& Analisys Journal of Applied Research, 10, 365-374. 